\title{
The Analysis of Performance-Based Budgeting in Immigration
}

\author{
Winda Dwi Gusti \\ Universitas Negeri Padang \\ Padang, Indonesia \\ dwiwinda96@gmail.com
}

\author{
Aldri Frinaldi \\ Public Administration Department \\ Universitas Negeri Padang \\ Padang, Indonesia \\ alfrinaldi@gmail.com ; aldri@fis.unp.ac.id
}

\author{
Zikri Alhadi \\ Public Administration Department \\ Universitas Negeri Padang \\ Padang, Indonesia \\ ianzikriunp@yahoo.co.id
}

\begin{abstract}
Performance-based budgeting ia a budgeting system have related between finance and performance target. Imbalance between budgetary absorption and the employee performance target make inefficiency of budget allocative. The purpose of performance-based budgeting system is increasing the efficiency and efectiveneee of public sector to looked performance measure in the budget process. In order to fulfill this porpuse, performance based budgeting was started to be implemented during 2010 for Ministry/Intitute in Indonesia. The result of this research shows budgeting in Immigration Office is incremental, the 2015 budget realization exceed the target that was decided in Ministry of Justice and Human Rights strategic plan 2015-2019, although there were a few program could not surpass the target because the program was incase. The obstacles that were faced by the Immigration Office Class 1 Padang to implement performance-based budgeting were communication, human resources, facilities and infrastructure completeness. The implementation of performance-based budgeting is very important the employee performance target effectively and efficiently, while Immigration Office Class 1 Padang cannot implement the performance-based budgeting principles maximally. It happens because the officials immigration need a training to change their mindset about the implementation of performance-based budgeting, and that is why training and socialization are needed.
\end{abstract}

Keywords-performance based budgeting; implementation; Immigration Office Class 1 Padang

\section{INTRODUCTION}

Budget is a statement of the performance estimates to achieved a certain period and expresed in financial measures. The budget have the function for regulating of economy and achievement of performance targets for an organization/ agency so as to minimize absorption of lowers budget, therefore needed reform of budgeting system. One forms of budget reform is very inflential to achievement of performance target is performance-based budgeting (PBB). PBB intended for enhacing efficiency and effectiveness budgeting in order to optimize the use of budget to measures the performance.

Importance of management effectiveness budgets began at budget preparation, budget execution and finally to reporting / accountability of the budget for government accountability, in connection with the functions of government in providing services to the citizen's [1]. But the reality of the budget issues included in income optimizing, budgets absorption and the problems to cover up defisit.

Budgeting forms for four stages, that is executive planning, legislative approval, executive implemetation and ez post accountability.There are two ways of pursuing efficiency in budget analysis. One known as "productive" efficiency, is to measure the ratio of outputs to inputs and has the object of tradition budget analysis. Another way, called "budgeting for results", measures the performance of different programs to allocate resources among them[2]. The budgets can be controlled by comparing the actual performance and budgets performance, calculates the difference of budgets, find the cause of be controlled and uncontrolled and stander revising fees or next years budget targets [3].

PBB first recognized in Amerika 1945s, because that are many failuresand begin to leave, but in decades 1990s, PBB considered useful and developed in conjunction with public administration reform. PBB is forms of budgeting system reform, because of the many flaws in the traditional budget. $\mathrm{PBB}$ is allocation of funds to achieve programmatic goals and objectives as well as some indication or measurement of work, efficiency and/or efectiveness [4]. PPB system s contributed a better and clearer understanding of agency budgetary needs [5]. PBB improve the efficiency of the allocation and productiivty of government spending. PBB intended to improve the performance of government inproviding services 
and products to its citizen's more efficienly and effectively [6]. PBB initiatives have attempted (e.g., maximing the ratio of outputs to inputs). Most recent PBB initiatives have attempted to improve so-called allocative efficiency by reallocating budget resources where they can return maximum benefit. PBB initiatives enhanced allocative efficiency of govermental programs [7].

PBB have yet to be implemented when the government have the hight commitment for increase of productivity and budget-efficiency, budget planning is low, lengthy process of budget deliberations, tender processing is slowly and fear of using budget is probles unresolved in Indonesia. The conceptual foundation for implemented of PBB that is (a) budget allocation is performance oriented (output and outcome oriented); (b) money follow function and; (c) presence of budget management flexibility while maintaining the principle of accountability (let the manager manages) [8].

When PBB successfully implemented, it can improve the productivity and allocative efficiency. PBB occurs when performance result are used to inform allocation decisions during budget preparation and execution [9].

In Indonesia, the implementation of PBB sees in Immigration Class 1 Padag, it's the unit of Ministry of Justice and Human Right. This research, less optimal implementation of PBB in Indonesia, especially in Immigration Office Class 1 Padang caused by their mind set of traditional budgeting for civil servant. With many problems in government financial needed reform of government financial, one of the budgets reform is traditional budgeting to PBB. This research defined to analyze of PBB implementation in Immigration Office Class 1 Padang.

\section{METHOD}

This research using of qualitative method without decriptive approach. Location studies in Immigration Office Class 1 Padang. The studies using purposive sampling method for determine informants. The informants in this research were 12 people. And data collection techniques that ware used in this research were interview, observation, and study documentation. Validity of data using triangulation techniques and to analyze of data use Miles and Huberman models.

\section{RESULT}

\section{A. Informants Characteristic}

TABLE 1. INFORMANTS OF RESEARCH

\begin{tabular}{|c|c|}
\hline \multicolumn{2}{|c|}{ Informants of Research } \\
\hline Substance & Number of people \\
\hline The Head Office & 1 \\
\hline Finance Affair & 4 \\
\hline Sub Section of Administrative & 3 \\
\hline The Head of Sections & 4 \\
\hline Total & 12 \\
\hline
\end{tabular}

Characteristic of informants is determine informants with considerates. The informants get to given maximally of data, the peoples is very understanding the issue of PBB. In Finance Affair as four peoples, they are is The Head of Finance Affair, commitment maker official, financial department official. In Sub Section of Administrative as two people, they are is The Head of Employee and The Head of General Division, and in The Head of Section as four people, they are is Information, Infrastructure and Communication Division, Traffic of Immigrations division, Imigrations Status Division and Immigrations Control Division. They are is peoples considerate to understanding about implementation of performance based budgeting in Immigration Office Class 1 Padang.

\section{B. Validity of Data Test}

Validity test using triangulation techniques. The kind of triangulation is (a) source triangulation, using to credibility of data by cheking of data with some resouces, to testing validity of data about PBB, then collection and testing of data going to the peoples is understanding about PBB implementation; (b) techniques triangulation, doing to cheking of data from the same source with differential techniques, in this sudies, data can to obtainab with interview, observation and documentation. One of documentation is budget documents in Immigration Office Class 1 Padang, then we can to analyze of budgets document based data-interview. Budget documents in this studies is Budget docements 2015 in Immigration Office Class 1 Padang.

\section{Result and Discussion}

PBB first recognized in Amerika 1945s, because that are many failuresand begin to leave, but in decades 1990s, PBB considered useful and developed in conjunction with public administration reform. In Indonesia, the reform of state finance management starting with declared of Low No.17/2003 about Government financial.

Then, in Regulation Ministry of Finance No. 136/PMK.02/2014 about The Manual Preparation and review of Work and Budget Plans of Ministries/ Agencies, the scope of performance based budgeting:

1. determine the vission and mission (which reflects the organization's strategy) goals, objectives and targets;

2. determine performance indicators, performance indicators is a quantitative measure that describe the level of achievement of a goal or goals that have been set. Therefor the perfrmance indicators that will have to be a calculated and measured and used a basis for assessing or see the level of performance both in the planning phase, the implementation phase or phase after completion and useful activities (work) Performance indicators includes: input, output, outcome, benefit and impact.

3. evaluation and decision making of the election and program priorities

4. standard cost analysis, is a standard cost of a program or activity so that the budget allocation becomes more rational 
The government of Indonesia has commited to implement PBB pilot project with a medium term perspective of six of the state ministries/agencies as early stages of 2009 [10]. One of the ministries that implement PBB is Ministry of Justice and Human Right in 2010s.

As the unit of Ministry of Justice and Human Right, Immigration also implement the PBB system. The Implemented of Performance based budgeting (PBB) in Immigration Office Class 1 Padang for budget preparation is incrementalism (define a budget planning with to increase of budget allocation for next years or current budgeting year). The 2015 budget realization exceed the target that was decided in Ministry of Justice and Human Rights strategic plan 20152019 that as $89,49 \%$, and the targets is $75 \%$. Absorption targets be provided as performance output, but the performance output is lower targets.

TABLE 2. THE OUTPUT OF PERFORMANCE IN IMMIGRATION OFFICE CLASS 1 PADANG 2015

\begin{tabular}{|c|c|c|c|c|c|}
\hline \multicolumn{6}{|c|}{ Performance Measures } \\
\hline The Aims & $\begin{array}{c}\text { Output } \\
\text { Indicators } \\
\text { (Activities) }\end{array}$ & $\begin{array}{c}\text { Budget( } \\
\text { Rp) }\end{array}$ & $\begin{array}{l}\text { Realizati-on } \\
\text { (Rp) }\end{array}$ & $\begin{array}{c}\text { Output } \\
(\%)\end{array}$ & $\begin{array}{c}\text { Target } \\
(\%)\end{array}$ \\
\hline \multirow{13}{*}{$\begin{array}{l}\text { All of Planning, } \\
\text { Actuating, } \\
\text { Controlling and } \\
\text { Evaluating at be } \\
\text { Ontime without } \\
\text { accountability } \\
\text { administratio-ns }\end{array}$} & \multicolumn{5}{|c|}{ Implementatively of activities support in Immigrasions facilities sector } \\
\hline & $\begin{array}{l}\text { Implemente-d of } \\
\text { activities in } \\
\text { Immigratio-ns } \\
\text { facilities sector }\end{array}$ & $\begin{array}{c}134.468 .0 \\
00\end{array}$ & 76.674 .300 & 57,02 & 75 \\
\hline & Office services & $\begin{array}{r}4.890 .819 \\
.000\end{array}$ & $\begin{array}{r}4.794 .384 .48 \\
3\end{array}$ & 98,03 & 75 \\
\hline & $\begin{array}{l}\text { Supplying of } \\
\text { motor vehicle, } \\
\text { Pengadaan } \\
\text { kendaraan } \\
\text { bermotor, set of } \\
\text { data processing, } \\
\text { equipment and } \\
\text { office facilities }\end{array}$ & $\begin{array}{c}1.462 .284 \\
.000\end{array}$ & $\begin{array}{c}1.273 .396 .92 \\
4\end{array}$ & 87,08 & 75 \\
\hline & The buildings & $\begin{array}{r}390.172 .0 \\
00 \\
\end{array}$ & 372.176 .500 & 95,39 & 75 \\
\hline & \multicolumn{5}{|c|}{ Publishing of Immgirations document accord with requested } \\
\hline & $\begin{array}{l}\text { Publishing of } \\
\text { Immigratio-ns } \\
\text { document for } \\
\text { foreigners }\end{array}$ & $\begin{array}{c}18.464 .00 \\
0\end{array}$ & 10.983 .500 & 59,49 & 75 \\
\hline & $\begin{array}{l}\text { Publishing of } \\
\text { Immigratio-ns } \\
\text { document for } \\
\text { Indonesia } \\
\text { citizen's }\end{array}$ & $\begin{array}{r}337.150 .0 \\
00\end{array}$ & 249.323 .600 & 73,95 & 75 \\
\hline & $\begin{array}{l}\text { Management of } \\
\text { information and } \\
\text { Immigratio-ns } \\
\text { communica-tion }\end{array}$ & $\begin{array}{c}201.690 .0 \\
00\end{array}$ & 68.233 .784 & 33,83 & 75 \\
\hline & \multicolumn{5}{|c|}{ Activities of Immigrations law enforced based legal form } \\
\hline & $\begin{array}{l}\text { Immigratio-ns } \\
\text { controlling }\end{array}$ & $\begin{array}{r}305.186 .0 \\
00 \\
\end{array}$ & 184.762 .820 & 60,54 & 75 \\
\hline & $\begin{array}{l}\text { Immigratio-ns } \\
\text { measuring }\end{array}$ & $\begin{array}{r}57.480 .00 \\
0 \\
\end{array}$ & 24.201 .960 & 42,11 & 75 \\
\hline & Deteni handling & $\begin{array}{r}28.700 .00 \\
0\end{array}$ & 546.000 & 1,90 & 75 \\
\hline
\end{tabular}

The table shows that some programs exceed the performance targets that is Implementatively of activities in Immigrasions facilities sector where virtually any aktivities exceed the target, while the publishing of Immigrations document and activities of Immigrations law enforced is be lower target. The output of performance target which still below $75 \%$ is document publishing Immigrations only reach $55,75 \%$, activities of Immigrations law enforced $34,05 \%$ and implementatively of activities support in Immigrasions facilities sector exceed the targets, that as $84,38 \%$.

Based on Government Instance Performance Report (Lakip) Immigration Office Class 1 Padang budget absorptions of 2015 is $89,49 \%$ (7.104.401.401). It's be good because nearly $100 \%$ and inversely with output of performance target, its caused are two things:

1. target two, percentage of document publishing Immigrations not yet $100 \%$ because the document out of square caused by: the network often offline, amount of aplicant data discrepancies, aplicant not ontime, depraved when printing documents.

2. target three, percentage of activities of Immigrations law enforced yet meet the targets because the activities are incase.

The problems to achieve peformance target, can be to evaluating for next years. Implementation of PBB can to sees by budget preparation. Immigration Office Class 1 Padang should to carry out of budget function. In the reality, the budget preparation to achieved the aims of organizational, that have plans of activities/ programs will be implemented, costplan will be produced and the result to be realized[11].

Budget preparation in Immigration Office Class 1 Padang have difined the aims and target that was decided in Ministry of Justice and Human Rights strategic plan 2015-2019, to achieve the aims and target the Immigration Office Class 1 Padang making any program/activities with budget-plans thereby indicative planning, and continued to make budget planning with the existing budget posture. Each such program has cost-allocative and percentage of achievement the performance target, and so that can be compared. There are three things the fundamental of PBB implementation that is output and outcome oriented, money follow function and let the manager manages[8]. In Immigration Office Class 1 Padang, budget allocation has been performance targets oriented which budgetary allocation of programs/activities based on functions of sub-department. each unit proposed of programs/activities for the Head Office and budget planning created by commitment maker official (PPK) and adjusted with the budgets. The budget management is openness although for implemented only held by PPK, users of budget authority (KPA), and treasurer. PBB has three principles, they are Tranparency, accountability and value for money [11]. The problem to impelemented PBB in Indonesia generally caused of mind set traditional budgeting. Allocative efficiency is more diffucult to achieve, due to the diffulculty of demanded performance measures with budget absorptions. But this has differentian in for each country's.

State PBB initiatives for U.S Department of Commerce (DOC), the U.S Department of Commerce (DOC) has been implementing PBB systems pursuant to Government Performance and Result Act (GPRA)-mandated performance evaluation requirements. Since PBB systems were applied to singles agency programs, one could expect that the DOC might not face typical challenges to successful implementation of PBB systems. Empirical findings, using eight years of budget data for DOC during the Bush administration, reveal that DOC bereau budget do not reflect performance evaluation scores. There is no evidence that budget resouces moved around different programs in the DOC in accordance with performance evaluation scores[7]. 
Same as in Indonesia, since PBB systems were applied to ministries/agencies, the problems in implementing PBB for budget preparation caused by mind set traditional budget, than to use an incrementalism rather than performance approach, the Immigration Class 1 Padang still use the incrementalism for budget preparation, and the implemetation of PBB, measures of performance not the primary aims, except for measures of budget absorption. Reveal that Imigration Class 1 Padang bereau budget do not reflect performance but reveal that budget absorption. This caused by demands of budget spending in order to achieve $100 \%$, meantime in PBB the primary aims is measures of performance not budgetabsorption. Failure to achieve the performance target for some work programs in Immigration Class 1 Padang described unsuccessly the implementation of PBB.

However, the fact that some public programs were successfully improving productive efficiency is partly due to the ability to measure outputs more easily [9]. For instance, the outcomes goal of the Immigration Office Class 1 Padang is all of planning, actuating, controlling and evaluating at be ontime without accountability administrations. The conclusion, the Implementation of PBB in Indonesia, especially in imiggration Office Class 1 Padang are not efficiently because they are priorities is to budget absorption. In other word, performance measure not be the first goals. Implementation of PBB has longtime to be emboided. Human resource issues in the government sector in Indonesia is still remains a major problem, especially in Immigration Office Class 1 Padang.

\section{CONCLUSION}

Based on the research in Immigration Office Class 1 Padang shows that the implementation of PBB has the problems. Budget preparation use the incremental approach, budget absorption is the primaly aims not to achieve of performance measures. This evidenced by budget absorption reaches $89,49 \%$, but the output of performance target which still below $75 \%$ is document publishing Immigrations only reach 55,75\%, activities of Immigrations law enforced $34,05 \%$ and implementatively of activities support in
Immigrasions facilities sector exceed the targets, that as $84,38 \%$. Research results indicates that the implement of PBB in Indonesia especially in Immigration Office Class Padang has the problems about mid set traditional budgeting. Human resources issues in Immigration Padang is still remains a major problem, generally in Indonesia.

\section{REFERENCES}

[1] Tamasoleng Aldstin. (2015). The Analyze of Budget-Management Effetiveness in Kepualauan Siau Tagulandang Biaro. Journal of Business Riset and Management. 98

[2] White,J. (2012). "Playing the Wrong PART; The Program Assessment Rating Tool and the Function of the President's Budget". Public Administration Review, 72(1):112-121)

[3] Mardiasmo. (2009). Accounting of Public Sector. Yogyakarta: ANDI

[4] Snell, R. and Hayes, K. (1993, November). Performance budgeting and the states. Presented to the Nebraska Legislative Appropriations Committee, Lincoln, NB.

[5] Ho, A.T. (2011). " PBB in American Local Governments: It's More than a Management Tool”. Public Administration Review, 71(3): 391-401

[6] Qi, Y., and Y.M., Mensah. (2012). An Empirical Analysis of the Effect of Performance Based Budgeting on State Government Expenditures. Research Paper, School of Business Administration China University of Petroleum and Center for Governmental Accounting Eucation and Research ritgers Business School, Rutgers University. Beijing and Rutgers, April 8

[7] Ryu, Jay Eungha. (2013). Performance Based Budgeting (PBB), Allocative Efficiency, and Budget Changes: The Case of the U.S Departement of Commerce. Public Finance and Management, PP 335 360

[8] Abdul Halim. (2014). Financial Management Public Sector: Problematics of Government revenues and axpenditures. Jakarta: Salemba Empat

[9] Robinson, M. \& Brumby, J. (2005) Does Performance Budgeting Work An Analytical Review of the Empirical Literature, Washington D.C: International Monetary fund, IMF Working Paper WP/05/210

[10] Meily Surianti. (2015). The Implementation of Performance Based Budgeting in Public Sector (Indonesia case: A literature review). Research Journal of Finance and Accounting

[11] Wahyudi Kumorotomo \& Erwan Agus Purwanto. (2005). Performance Based Budgeting, Concept and Aplicant. Yogyakarta: MAP UGM 